\title{
HUBUNGAN DUKUNGAN KELUARGA DENGAN KUALITAS HIDUP LANSIA PADA MASA COVID-19
}

\author{
Tiara Putri Wiraini ${ }^{1)}$, Ririn Muthia Zukhra ${ }^{2)}$, Yesi Hasneli ${ }^{3)}$ \\ ${ }^{1,2,3}$ Fakultas Keperawatan, Universitas Riau \\ Email:ptiara17@yahoo.co.id
}

\begin{abstract}
ABSTRAK
Lansia merupakan salah satu yang rentan terhadap penularan Covid-19 dikarenakan rendahnya imunitas tubuh dan penyakit kronis yang dialami lansia. Dukungan keluarga sangat diperlukan agar kualitas hidup dan kesehatan lansia tetap terjaga secara optimal. Penelitian ini bertujuan untuk mengetahui hubungan dukungan keluarga dengan kualitas hidup lansia pada masa Covid-19. Penelitian ini merupakan penelitian kuantitatif dengan desain deskriptif korelasi dan pendekatan cross sectional. Teknik pengambilan sampel adalah Purposive Sampling dengan jumlah responden 125 responden. Alat pengumpulan data yang digunakan adalah kuesioner dukungan keluarga dan kualitas hidup WHOQOL-BREF. Hasil penelitian ini menunjukkan dukungan keluarga dengan kategori baik (70.4\%) dan kualitas hidup lansia dengan kategori baik (89\%). Hasil uji statistik menggunakan uji fisher's diperoleh nilai $p$ value $<\alpha(0.05)$, sehingga dapat disimpulkan bahwa ada hubungan yang signifikan antara dukungan keluarga dengan kualitas hidup lansia pada masa Covid-19. Nilai Odd Ratio 41.760 menunjukkan lansia yang dukungan keluarga baik maka kualitas hidupnya mempunyai peluang 41.760 kali lebih baik. Rekomendasi untuk penelitian selanjutnya membahas faktor kualitas hidup lebih domain (misalnya, domain fisik, psikososial, sosial dan lingkungan) dan memasukkan lansia tinggal dengan pasangan/sendiri kedalam inklusi.
\end{abstract}

Kata Kunci: Covid-19, Dukungan Keluarga, Kualitas Hidup, Lansia

ABSTRACT
The elderly are among those who are vulnerable to Covid-19 transmission due to low immunity and chronic diseases experienced by the elderly. Family support is needed so that the quality of life and health of the elderly are maintained optimally. This study aims to determine the relationship between family support and the quality of life of the elderly during the Covid-19 period. This research is a quantitative study with a descriptive correlation design and a cross sectional approach. The sampling technique was purposive sampling with 125 respondents. The sampling technique wa the WHOQOL$B R E F$ family support and quality of life questionnaire. The results of this study indicate that family support is in a good category (70.4\%) and the quality of life of the elderly is in a good category (89\%). The results of statistical tests using fisher's test obtained $p$ value $<\alpha(0.05)$, so it can be concluded that there is a significant relationship between family support and the quality of life of the elderly during the Covid-19 period. The Odd Ratio value of 41,760 shows that elderly people with good family support have a 41,760 times better quality of life. Recommendations for future research address quality of life factors in more domains (eg, physical, psychosocial, social and environmental domains) and include elderly living with a partner / alone into inclusion.

Keywords: Covid-19, Family Support, Quality of Life, Elderly

\section{PENDAHULUAN}

Covid-19 atau yang dikenal sebagai novel coronavirus pertama kali terjadi di kota Wuhan, China pada bulan Desember 2019 dan mulai menyebar ke negara lain pada bulan Januari 2020. Negara Indonesia sendiri telah mengumumkan kasus Covid19 pada bulan Maret 2020. Penyebaran Covid-19 pada saat ini merupakan bencana kesehatan global yang paling kritis, dimana telah menginfeksi lebih dari 100 negara dan menyebabkan 6400 kematian. World Health Organization (WHO) menyatakan Covid-19 sebagai pandemi, dimana telah menyebar dan menularkan virus pada penduduk hampir di seluruh dunia (Kirana, Rajagukguk, \& Lubis 2020) Menurut data Worldmeter pada tanggal 07 Januri 2021, 
kasus Covid-19 terus meningkat yakni sebanyak 87.640.097 kasus yang telah terjadi di seluruh dunia. Negara yang menempati peringkat tertinggi kasus Covid19 yaitu Amerika Serikat sebanyak 21.857.616 kasus, sedangkan Indonesia menempati peringkat ke-20 dari 220 negara yang terinfeksi Covid-19, dimana jumlah total kasus sebanyak 797.723 kasus (Worldmeter, 2021).

Data Dinas Kesehatan Riau pada tanggal 07 Januari 2021, dengan kasus total terkonfirmasi sebanyak 25.806 kasus dengan penambahan 139 kasus. Jumlah Covid-19 tertinggi berada di Pekanbaru sebanyak 12052. Untuk data di Puskesmas Payung Sekaki didapatkan penambahan kasus sebanyak 4 kasus (Dinkes Riau, 2021).

Jumlah penderita Covid-19 terus meningkat, kelompok lanjut usia sering dikaitkan dengan kelompok yang rentan yang dimana kasus kematian terbanyak terjadi pada pasien Covid-19 berusia 80 tahun (Kemenkes, 2020). Hal ini dibuktikan dari penelitian yang dilakukan oleh Siagian (2020) tentang "Mencari kelompok rentan terinfeksi Virus Corona dengan metode Discourse Network Analysis" Hasil studi menunjukkan penderita penyakit kronis, perokok, penghisap vape, kaum pria, orang bergolongan darah A dan kelompok lansia termasuk kelompok rentan terinfeksi Covid19.

Lansia merupakan masa dimana seseorang telah menjadi dewasa yang memiliki penurunan kemampuan tubuh untuk beradaptasi terhadap stres lingkungan dan juga ditandai dengan fungsi biologis, psikologis, sosial dan ekonominya menurun (Muhith, 2016). WHO membagi lansia menjadi empat kelompok umur, yaitu usia pertengahan (middle age) 45-59 tahun, lanjut usia (elderly) 60-74 tahun, lanjut usia tua (old) 75-90 tahun dan usia sangat tua (very old) di atas 90 tahun (Hartati, 2017). Berdasarkan peraturan menteri sosial Nomor 5 tahun 2018 lanjut usia adalah mereka yang telah berusia 60 tahun ke atas (Permensos, 2018).
Salah satu penyebab utama kerentanan lansia terhadap Covid-19 adalah rendahnya imunitas tubuh, hal ini terjadi karena sistem imun tubuh pada lansia tidak dapat bekerja sekeras saat mereka masih muda, karena seiring bertambahnya usia, fungsi organ tubuh juga menurun. Penurunan imunitas akibat proses penuaan meliputi penurunan produksi pigmen rambut, produksi hormon, elastisitas kulit, massa otot, kepadatan tulang, kekuatan gigi, dan fungsi organ-organ tubuh lainnya. Selain itu, banyaknya lansia yang menderita penyakit kronis, seperti penyakit jantung, diabetes, asma atau kanker. Hal ini akan meningkatkan risiko Covid-19, komplikasi akibat Covid-19 juga akan semakin parah, jika lansia sudah menderita penyakit tersebut (Portal Informasi Indonesia, 2020).

Menurut data World Population Prosepect: the 2017 Revesion, pada tahun 2025 populasi lansia diperkirakan akan meningkat sekitar $14.9 \%$ dan pada tahun 2030 populasi lansia akan mencapai $16.4 \%$. Sedangkan di Indonesia, menurut data ramalan penduduk tahun 2017 , diperkirakan jumlah lansia pada tahun 2020 (27.08 juta), tahun 2025 (33.69 juta) dan tahun 2035 (48.19 juta) (Kemenkes R1, 2017).

Dinas Kesehatan Kota Pekanbaru (2020) melaporkan dari 21 Puskesmas yang ada di Pekanbaru, Puskesmas Payung Sekaki merupakan Puskesmas yang memiliki populasi lansia tertinggi yang ada di Kota Pekanbaru sebanyak 6.327 orang dengan jumlah lansia laki-laki sebanyak 3.144 orang dan jumlah lansia perempuan sebanyak 3.184 orang. Berdasarkan data Puskesmas Payung Sekaki pada bulan Mei sampai bulan Agustus 2020, jumlah seluruh kunjungan lansia di Puskesmas Payung Sekaki sebanyak 743 orang.

Jumlah lansia yang terus meningkat dari tahun ke tahun akan berdampak pada kesejahteraan lansia (Kementerian Kesehatan Republik Indonesia, 2014). Meningkatnya jumlah populasi lansia yang diiringi dengan meningkatnya masalah yang dihadapi akan berdampak pada kualitas hidup lansia. 
Menurut WHO kualitas hidup adalah persepsi seseorang tentang kehidupan yang berkaitan dengan tujuan, harapan, standar dan perhatian hidup dalam konteks budaya dan norma. Kualitas hidup lansia dipengaruhi oleh tingkat kesehatan, spiritualitas, harga diri dan dukungan sosial. Kualitas hidup lansia terdiri dari beberapa aspek yaitu kesehatan fisik, kesejahteraan psikologis, hubungan sosial dan hubungan dengan lingkungan yang mempengaruhi kualitas hidup (Dewi, 2014). Jika aspekaspek tersebut dapat dipenuhi maka kualitas hidup lansia akan menjadi lebih baik (Ummah, 2016).

Lansia yang mempunyai kualitas
hidup lebih baik akan mampu meningkatkan produktivitas, mempunyai semangat dan kesejahteraan yang tinggi dalam kehidupannya. Rendahnya kualitas hidup lansia biasanya terkait dengan fungsi keluarga, dukungan sosial, dukungan sosial pasangan, dukungan sosial masyarakat dan dukungan keluarga. Dukungan keluarga merupakan aspek penting dalam membantu seseorang dalam memecahkan masalah. Seseorang akan mendapatkan rasa percaya diri yang tinggi, motivasi menghadapi masalah, serta meningkatkan kepuasan hidup dengan adanya dukungan keluarga (Pratiwi, 2015).

Dukungan keluarga sangat diperlukan lansia agar kualitas hidup dan kesehatan lansia dapat tetap terjaga seoptimal mungkin selama masa Covid-19, hal yang perlu diperhatikan keluarga yang tinggal bersama lansia selama masa Covid19 ialah memastikan bahwa lansia tidak terpapar dengan Covid-19. Keluarga perlu memperhatikan protokol kesehatan dan memastikan bahwa seluruh anggota keluarga khususnya lansia mengikuti aturan protokol kesehatan seperti memakai masker, cuci tangan, dan physical distancing.

Penerapan social distancing dan physical distancing telah memicu munculnya masalah keterasingan pada lanjut usia di masa pandemi. pemberlakuan pembatasan sosial skala besar (PSBB) dan larangan mudik 2020 yang bertujuan memutus rantai penularan Covid-19 dapat memicu timbulnya masalah psikologis (Tristano, 2020). Akibat adanya physical distancing lansia yang tidak tinggal bersama keluarga akan merasa sedih dan kesepian karena tidak sering dikunjungi seperti biasanya oleh anak-anaknya, sehingga keluarga harus sering menghubungi dan menanyakan kabar lansia melalui via ponsel agar lansia tidak merasa sedih dan kesepian.

Penelitian ini sejalan dengan penelitian yang dilakukan oleh Waluya dan Muhamad (2018) mengenai "Hubungan dukungan keluarga dengan kualitas hidup lansia di RW 10 kelurahan Cisarua Wilayah Kerja Puskesmas Sukabumi Kota Sukabumi" menggunakan UjiSomers'D didapatkan $P$ value $=0,000$ menunjukkan bahwa terdapat hubungan antara dukungan keluarga dengan kualitas hidup lansia di RW 10 kelurahan Cisarua Wilayah Kerja Puskesmas Sukabumi Kota Sukabumi.

Penelitian yang telah diuraikan diatas menunjukkan adanya hubungan yang signifikan. Adapun penelitian tersebut menggambarkan dukungan keluarga terhadap kualitas hidup lansia pada masa sebelum terjadinya Covid-19. Sejauh ini, Covid-19 diyakini menyebabkan infeksi dan kematian yang lebih serius di kalangan lansia dibandingkan orang dewasa atau anak-anak (Tim Dosen Fakultas Kedokteran Unisba, 2020). Hal ini terbukti dari Konperensi Pers di BNPB 19 Maret 2020, di mana Achmad Yurianto juru bicara Tim Gugus Tugas Percepatan Penanggulangan Virus Covid-19 mengatakan bahwa 24 dari 25 kematian berusia 40 tahun keatas $(96 \%)$ (Kemenkes, 2020).

Berdasarkan studi pendahuluan yang dilakukan peneliti pada tanggal 21 September 2020 dengan hasil wawancara singkat kepada 8 responden di Wilayah Kerja Puskesmas Payung Sekaki Pekanbaru didapatkan hasil dari 5 responden kurang mendapatkan dukungan keluarga pada masa Covid-19. Lansia mengatakan cenderung sensitif, mudah tersinggung, mudah marah dengan ucapan orang lain, sering merasa kesepian dan merasa cemas akan kesehatannya karena Covid-19 ini. Hal tersebut menujukkan bahwa kondisi fisik 
dan psikis dari lansia tersebut kurang baik sehingga dapat mempengaruhi kualitas hidupnya, mereka datang ke Puskesmas Payung Sekaki tanpa ditemani keluarga dan ada beberapa yang datang bersama suaminya dikarenakan anak-anaknya sibuk dengan kegiatan masing-masing.

Sebelum masa Covid-19 maupun sampai terjadinya masa Covid-19 mereka mengatakan bahwa keluarganya jarang memperhatikan keadaan mereka, keluarga cenderung sibuk dengan urusan mereka masing-masing, hal ini membuat mereka justru merasa kurang bahagia. Anakanaknya hanya sekedar menanyakan kesehatan saja tanpa memberikan perhatian lebih seperti: memberikan obat, menyuapkan makan bahkan untuk menemani duduk di sore haripun anaknya tidak memiliki waktu.

Berdasarkan uraian diatas penulis melakukan penelitian bertujuan untuk mengetahui tentang Hubungan dukungan keluarga dengan kualitas hidup lansia pada masa Covid-19".

\section{METODE PENELITIAN}

Penelitian ini dilaksanakan di Wilayah Kerja Puskesmas Payung Sekaki. Penelitian ini merupakan penelitian kuantitatif dengan desain deskriptif korelasi dan menggunakan pendekatan cross sectional. Populasi penelitian ini adalah seluruh lansia yang berada dalam cakupan Wilayah Kerja Puskesmas Payung Sekaki. Pengambilan sampel dilakukan secara purposive sampling sesuai dengan kriteria inklusi sebanyak 125 responden yaitu, lansia yang tinggal bersama keluaga minimal 1 anggota keluarga, tidak memiliki gangguan kognitif, dapat berkomunikasi dengan baik, keadaan umum dan respon masih bagus serta bersedia menjadi responden.

Alat pengumpulan data yang digunakan adalah kuesioner. Kuesioner dukungan keluarga yang telah dilakukan uji validitas dan uji reliabilitas di Wilayah Kerja Puskesmas Sidomulyo dengan hasil uji validitas (0.483-0.897) dan uji reliabilitas $(\alpha=0.941)$, untuk kuesioner kualitas hidup WHOQOL-BREF tidak dilakukan uji validitas dan reliabilitas dikarenakan kuesioner sudah baku.

Pengumpulan data dilakukan secara online dengan mewawancarai responden melalui ponsel/telepon untuk menjawab pertanyaan dari kuesioner. Data yang dikumpulkan meliputi karakteristik responden, dukungan keluarga dan kualitas hidup lansia pada masa Covid-19.

Analisis data dilakukan secara univariat dan bivariat. Analisis univariat digunakan untuk mendeskripsikan mengenai karakteristik responden (umur, jenis kelamin, status, pendidikan, pekerjaan), gambaran dukungan keluarga dan gambaran kualitas hidup lansia pada masa Covid-19. Analisa bivariat digunakan untuk mengetahui hubungan dukungan keluarga dengan kualitas hidup lansia pada masa Covid-19 dengan uji Fisher's Exact Test. Data dianalisis secara deskriptif dalam bentuk tabel distribusi frekuensi.

\section{HASIL PENELITIAN}

\section{A. Analisa Univariat}

\section{Karakteristik Responden}

Berdasarkan hasil penelitian dapat diketahui distribusi frekuensi karakteristik responden pada tabel 1 sebagai berikut:

Tabel 1. Distribusi frekuensi karakteristik responden berdasarkan umur, jenis kelamin, status, pendidikan, pekerjaan, tinggal bersama dan penghasilan berasal di Wilayah Kerja Puskesmas Payung Sekaki Pekanbaru. 


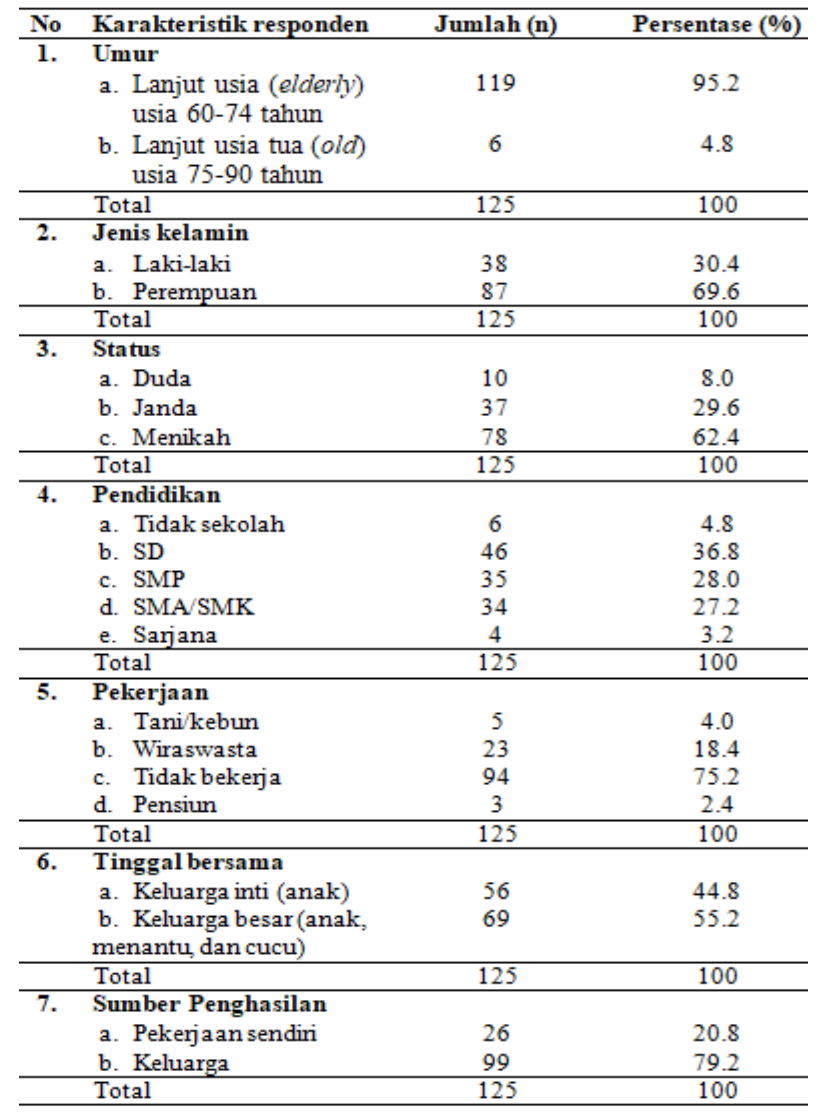

Dari hasil tabel 1 diketahui bahwa mayoritas responden berusia 60-74 tahun sebanyak 119 orang (95.2\%), mayoritas responden berjenis kelamin perempuan sebanyak 87 orang (69.6\%), mayoritas responden berstatus menikah sebanyak 78 orang (62.4\%), mayoritas responden dengan tingkat pendidikan SD sebanyak 46 orang $(36.8 \%)$, mayoritas responden tidak bekerja sebanyak 94 orang $(75.2 \%)$, mayoritas responden tinggal bersama keluarga besar sebanyak 69 orang $(55.2 \%)$ dan mayoritas responden memperoleh penghasilan dari keluarga sebanyak 99 orang $(79.2 \%)$.

\section{Dukungan keluarga}

Berdasarkan hasil penelitian dapat diketahui distribusi frekuensi dukungan keluarga pada tabel 2 sebagai berikut:

Tabel 2. Distribusi frekuensi dukungan keluarga lansia pada masa Covid-19

\begin{tabular}{llcc}
\hline No & Dukungan keluarga & Junlah (in) & Persentase (\%) \\
\hline 1. & Baik & 88 & 70.4 \\
2. & Kurang & 37 & 29.6 \\
\hline & Total & 125 & 100 \\
\hline
\end{tabular}

Dari hasil tabel 2 diketahui bahwa mayoritas responden memperoleh dukungan yang baik dari keluarga sebanyak 88 orang $(70.4 \%)$.

\section{Kualitas Hidup}

Berdasarkan hasil penelitian dapat diketahui distribusi frekuensi dukungan keluarga pada tabel 3 sebagai berikut:

Tabel 3 . Distribusi frekuensi kualitas hidup lansia pada masa Covid-19

\begin{tabular}{llcc}
\hline No & Kualitas hidup & Jumlah (n) & Persentase (\%) \\
\hline 1. & Baik & 112 & 89.6 \\
2. & Kurang & 13 & 10.4 \\
\hline & Total & 125 & 100 \\
\hline
\end{tabular}

Dari hasil tabel 3 diketahui mayoritas responden memiliki kualitas hidup yang baik sebanyak 112 orang (89.6\%).

\section{B. Analisa Bivariat}

Berdasarkan hasil penelitian dapat diketahui distribusi hubungan dukungan keluarga dengan kualitas hidup lansia pada tabel 4 sebagai berikut:

Tabel 4. Distribusi hubungan dukungan keluarga dengan kualitas hidup lansia pada masa Covid-19

\begin{tabular}{|c|c|c|c|c|c|c|c|c|c|}
\hline \multirow{3}{*}{$\begin{array}{l}N \\
0\end{array}$} & \multirow{3}{*}{$\begin{array}{l}\text { Dukungan } \\
\text { Keluarga }\end{array}$} & \multicolumn{4}{|c|}{ Kualitas lidup lansia } & \multirow{2}{*}{\multicolumn{2}{|c|}{ Total }} & \multirow[b]{2}{*}{$\mathrm{OR}$} & \multirow[b]{2}{*}{$\begin{array}{c}p- \\
\text { value }\end{array}$} \\
\hline & & Baik & & Kurang & & & & & \\
\hline & & $\mathrm{F}$ & $\%$ & $\mathrm{~F}$ & $\%$ & $\mathrm{~F}$ & $\%$ & & \\
\hline 1. & Baik & 87 & 69.6 & 1 & 0.8 & 88 & 70.4 & 41.760 & 0.000 \\
\hline 2. & Kurang & 25 & 20.0 & 12 & 9.6 & 37 & 29.6 & & \\
\hline & Total & 112 & 89.6 & 13 & 10.4 & 125 & 100 & & \\
\hline
\end{tabular}

Dari hasil tabel 4 diketahui bahwa hasil analisa data bivariat diperoleh mayoritas responden yang mendapatkan dukungan keluarga baik memiliki kualitas hidup baik sebanyak 87 orang (69.6\%), sedangkan responden dengan dukungan keluarga kurang memiliki kualitas hidup kurang sebanyak 12 orang $(9.6 \%)$.

Berdasarkan hasil uji Fisher's, diperoleh nilai $p$ value $=0.000$ ( $p$ value $<$ 0.05), berarti Ho ditolak sehingga dapat disimpulkan bahwa ada hubungan yang signifikan antara dukungan keluarga dengan kualitas hidup lansia pada masa Covid-19 di Wilayah Kerja Puskesmas Payung Sekaki Pekanbaru.

Hasil analisis diperoleh nilai Odd Ratio 41.760 artinya lansia yang dukungan 
keluarga baik maka kualitas hidupnya mempunyai peluang 41.760 kali lebih baik dibandingkan lansia yang dukungan keluarga kurang.

\section{PEMBAHASAN}

\section{A. Analisa Univariat}

\section{Karakteristik Responden}

Gambaran mayoritas responden berada dalam lansia (elderly) usia 60-74 tahun. Sehingga dapat disimpulkan bahwa responden yang berada di Wilayah Kerja Puskesmas Payung Sekaki pada umumnya berusia 60 tahun keatas.

Gambaran mayoritas responden berjenis kelamin perempuan, Hal tersebut disebabkan dari data sekunder yang peneliti dapatkan dari kader dan buku rekam medis responden di Puskesmas Payung Sekaki jumlah lansia dengan jenis kelamin perempuan lebih banyak dibandingkan lakilaki.

Gambaran mayoritas responden berstatus menikah. Hal tersebut disebabkan karena responden masih tinggal bersama pasangan hidup. Pernikahan erat kaitannya dengan cinta dan kasih sayang yang dibutuhkan oleh lansia, dimana mereka selalu berbagi serta saling membantu secara fisik maupun psikologis.

Gambaran mayoritas responden tingkat pendidikan SD. Sehingga dapat dikatakan bahwa tingkat pendidikan responden tergolong rendah $\mathrm{Hal}$ tersebut disebabkan karena responden tidak memiliki cukup biaya untuk meneruskan sekolah ke tingkat yang lebih tinggi.

Gambaran mayoritas responden tidak bekerja. Hal tersebut disebabkan karena responden tidak memiliki pekerjaan dikarenakan pendidikan rendah dan tidak mampunyai kekuatan lebih untuk melakukan aktivitas berat serta ditambahnya pada masa pandemi Covid-19 saat ini yang membuat lansia harus tetap dirumah agar terhindar dari penyebaran Covid-19.

Gambaran mayoritas responden tinggal bersama keluarga besar (anak, menantu dan cucu). Berdasarkan wawancara yang dilakukan peneliti didapatkan responden yang tinggal bersama keluarga besar apalagi selama masa Covid19 ini membuatnya merasa diperhatikan oleh keluarga, dimana keluarga selalu menyediakan fasilitas untuk kebutuhan sehari-hari dan pengobatan. Lansia juga tidak merasa kesepian dikarenakan adanya cucu dirumah yang selalu membuatnya tertawa dan bahagia.

Gambaran bahwa mayoritas responden memperoleh penghasilan dari keluarga. Pendapatan lansia yang menurun akan merubah status lansia dari kelompok "berpenghasilan" menjadi kelompok "tergantung" pada anak-anak mereka, dikarenakan pandemi Covid-19 akan memengaruhi ekonomi dengan berkurangnya penghasilan ataupun hilangnya penghasilan, sehingga pemberian yang didapat lansia dari anak-anak di rantau juga berkurang (Tristanto, 2020).

\section{Dukungan keluarga}

Gambaran dukungan keluarga pada penelitian yang dilakukan di Wilayah Kerja Puskesmas Payung Sekaki menunjukkan bahwa 88 orang $(70.4 \%)$ responden mengalami dukungan keluarga baik sedangkan 37 orang $(29.6 \%)$ responden mengalami dukungan keluarga yang kurang. Untuk meningkatkan kualitas hidup lansia diperlukan dukungan keluarga agar lansia dapat tetap terjaga kesehatannya seoptimal mungkin selama masa Covid-19 saat ini.

Berdasarkan wawancara melalui ponsel, hasil penelitian menunjukkan bahwa bentuk dukungan emosional yang didapatkan selama masa Covid-19, mayoritas keluarga sering mendampingi lansia dalam menjalani perawatan dirumah sebanyak 101 orang $(80.8 \%)$.

Hal ini sesuai dengan teori menyatakan bahwa dukungan yang dapat diberikan keluarga pada masa Covid-19 yaitu, jadilah pendamping dan pendengar yang baik apabila lansia membutuhkan teman berbicara untuk menceritakan masalah yang dihadapi. Berikan juga pujian dan arahan positif dengan tetap memperhatikan jarak fisik (Kemenkes RI, 2020). 
Bentuk dukungan instrumental yang didapatkan selama masa Covid-19, mayoritas keluarga sering berusaha mencarikan kekurangan sarana dan peralatan perawatan yang diperlukan lansia sebanyak 76 orang $(60.8 \%)$.

Hal ini sesuai dengan teori bahwa dukungan yang dapat diberikan oleh keluarga pada masa Covid-19 kepada lansia yaitu, menyediakan peralatan perawatan dan pengobatan yang diperlukan serta, menyediakan masker, handsanitizer, makanan bergizi dan multivitamin (Kemenkes RI, 2020).

Bentuk dukungan informasional yang didapatkan selama masa Covid-1,9 mayoritas keluarga selalu mengingatkan ketika lansia keluar rumah untuk selalu mematuhi protokol kesehatan sebanyak 92 orang $(73.6 \%)$.

Hal ini sesuai dengan teori menyatakan bahwa dukungan yang dapat diberikan keluarga pada masa Covid-19 yaitu memberikan pemahaman kepada lansia mengenai pencegahan penularan pandemi Covid-19 dengan selalu menerapkan protokol kesehatan seperti memakai masker, mengkonsumsi makanan sehat dan minum vitamin serta menjaga jarak sosial (Social Distancing) (Kemenkes RI, 2020).

Bentuk dukungan penghargaan yang didapatkan selama masa Covid-19, mayoritas keluarga selalu melibatkan lansia dalam aktivitas dirumah sebanyak 80 orang $(64.0 \%)$. Hal ini sesuai dengan teori menyatakan bahwa dukungan yang dapat diberikan keluarga pada masa Covid-19 yaitu, menemani lansia melakukan aktivitas dan hobi lansia dirumah. Keluarga juga dapat menganjurkan dan mengajarkan lansia cara menggunakan alat komunikasi jarak jauh seperti telepon seluler, serta menggunakan sarana pertemuan virtual online agar lansia bisa menghubungi temannya (Kemenkes RI, 2020).

Bentuk dukungan keluarga yang telah diuraikan diatas sesuai dengan bentuk ciriciri dukungan keluarga menurut Harnilawati (2013) yang terdiri dari perhatian emosional, bantuan informational, bantuan instrumental dan bantuan penghargaan.

\section{Kualitas hidup lansia}

Berdasarkan hasil gambaran kualitas hidup lansia pada penelitian yang dilakukan di Wilayah Kerja Puskesmas Payung Sekaki menunjukkan bahwa 112 orang $(89.6 \%)$ responden mengalami kualitas hidup baik sedangkan 13 orang (10.4\%) responden mengalami kualitas hidup yang kurang.

Berdasarkan wawancara melalui ponsel, hasil penelitian menunjukkan bahwa lansia yang memiliki kualitas hidup baik dikarenakan lansia masih mampu mandiri dalam melakukan aktivitas seharisehari tanpa tergantung pada anggota keluarganya dan lansia juga dapat mengurus kebutuhan pribadinya sendiri.

Berdasarkan wawancara melalui ponsel, hasil penelitian dari 125 responden menunjukkan bahwa pertanyaan umum yang dijawab responden yang memiliki kualitas hidup baik sebanyak 73 orang (58.4\%) dan memuaskan terhadap kesehatan sebanyak 100 orang $(80.0 \%)$.

Hasil domain kesehatan fisik menunjukkan mayoritas responden yang sering sekali memiliki vitalitas yang cukup untuk beraktivitas sehari sebanyak 89 orang (71.2\%). Hal ini sesuai dengan Tristanto (2020) megemukakan bahwa penurunan produksi hormon yang dialami lansia merupakan masalah fisiologis yang menyebabkan terganggunya kualitas hidup lansia dan berujung pada penyakit kronis.

Pada masa Covid-19 saat ini, WHO menyatakan bahwa lansia yang sudah memiliki penyakit kronis lebih rentan terkena infeksi karena kekebalan tubuhnya yang terus menurun. Hal ini sesuai dengan teori Kemenkes RI (2020) yaitu sistem kekebalan yang melemah dan adanya penyakit kronis pada lansia dapat meningkatkan risiko infeksi Covid-19 dan risiko virus serius lainnya.

Hasil domain psikologis menunjukkan mayoritas responden sangat sering menikmati hidup sebanyak 89 orang (71.2\%). Hal ini sesuai dengan Imanda (2016) mengatakan kualitas hidup 
merupakan persepsi dari seseorang dalam kehidupannya sebagai suatu terminologi yang menunjukkan keadaan mengenai kesehatan baik fisik, sosial, psikologis serta kemampuan dalam melakukan aktivitas sehari-hari.

Hasil domain hubungan sosial menunjukkan mayoritas responden yang merasakan biasa saja dalam kehidupan seksualnya sebanyak 69 orang $(55.2 \%)$ dan domain lingkungan menunjukkan mayoritas responden yang sangat sering merasa sehat dengan lingkungan tempat tinggalnya sebanyak 100 orang $(80.0 \%)$.

Hasil penelitian yang telah didapatkan dan diuraikan tersebut sesuai dengan teori WHOQOL-BREF (2012) empat domain yang dapat meningkatkan kualitas hidup lansia yaitu, kesehatan fisik (menggambarkan kemampuan dalam lansia dalam menyelesaikan aktivitas seharisehari), kesejahteraan psikologis (menggambarkan perasaan meyenangkan yang dirasakan oleh lansia), hubungan sosial (menggambarkan penerimaan lansia terhadap masyarakat di lingkungan sekitar) dan hubungan dengan lingkungan (menggambarkan keadaan tempat tinggal lansia yang aman dan menerima perlindungan sosial di lingkungannya).

\section{B. Analisa Bivariat}

Berdasarkan hasil penelitian didapatkan uji Fisher's antara dukungan keluarga dengan kualitas hidup lansia $p$ value $=0.000(p$-value $<0.05)$. Sehingga dapat diambil kesimpulan bahwa Ho ditolak yang artinya ada hubungan dukungan keluarga dengan kualitas hidup lansia pada masa Covid-19.

Hasil penelitian yang telah dilakukan diperoleh 87 orang $(69 \%)$ menunjukkan dukungan keluarga baik memiliki kualitas hidup baik. Berdasakan hasil wawancara melalui ponsel, menunjukkan bahwa selama masa Covid-19 saat ini keluarga memberikan perhatian dan kasih sayang, menyediakan fasilitas, mengingatkan agar selalu menerapkan protokol kesehatan, mengikut sertakan lansia dalam aktivitas keluarga dan keluarga juga tidak melarang lansia berhubungan dengan temannya melalui ponsel/online, hal ini membuat perasaan lansia menjadi lebih senang dan bahagia. Sehingga dapat diartikan bahwa jika lansia mendapatkan dukungan keluarga baik maka lansia akan memiliki kualitas hidup yang lebih baik.

Hal ini sesuai dengan penelitian yang dilakukan oleh Tristanto (2020) menyatakan bahwa salah satu bentuk dukungan keluarga yang dapat dilakukan keluarga selama masa Covid-19 saat ini yaitu, anggota keluarga tetap menghormati, menghargai, memperhatikan dan memperbolehkan lansia untuk berpartisipasi dalam kegiatan keluarga dengan tetap memperhatikan jarak fisik dan sosial, serta memfasilitasi lansia untuk mengenang masa lalu yang menyenangkan dengan menceritakannya kepada anggota keluarga agar lansia tetap merasa bahagia.

Hasil penelitian ini juga menunjukkan dukungan keluarga kurang memiliki kualitas hidup kurang sebanyak 12 orang $(9.6) \%$. Berdasarkan hasil wawancara melalui via ponsel, menunjukkan bahwa beberapa lansia merasakan cemas dengan Covid-19 saat ini, dikarenakan Covid-19 ini telah menyebar luas disetiap daerah ditambah lagi yang memiliki penyakit bawaan yang membuat lansia semakin rentan terhadap Covid-19.

Lansia yang memiliki kualitas hidup kurang berkaitan juga dengan umur, hal ini diperkuat dengan hasil wawancara dari beberapa lansia yang mengatakan kurang mampu/puas melakukan aktivitasnya dengan baik dikarenakan semakin tua umur lansia maka kemampuan fisik akan semakin menurun sehingga kualitas hidup lansia juga akan semakin menurun.

Hal ini diharapkan lansia yang mengalami kualitas hidup kurang dapat diberikan dukungan keluarga agar lansia dapat meningkatkan kualitas hidupnya. Menurut Pratiwi (2015) mengatakan bahwa salah satu faktor yang mempengaruhi kualitas hidup seseorang yaitu dukungan dari lingkungan keluarga.

Pada masa Covid-19 saat ini bentuk dukungan keluarga yang dapat diberikan 
kepada lansia antara lain keluarga memberikan motivasi lansia untuk dapat menyesuaikan diri agar tidak cemas terhadap Covid-19 dengan selalu menerapkan protokol kesehatan.

Keluarga juga di harapkan dapat memotivasi lansia untuk merubah perilaku dan gaya hidup sehat agar lansia tetap bisa menjaga status kesehatannya dengan mengkonsumsi makanan yang sehat, minum vitamin, olahraga teratur dirumah serta istirahat yang cukup. Hal ini dapat dikatakan bahwa dengan adanya dukungan keluarga, lansia akan merasa terbantu dalam menghadapi masalah serta merasa aman dengan adanya dukungan keluarga, dengan demikian dapat disimpulkan dukungan keluarga yang baik akan menghasilkan kualitas hidup yang lebih baik.

Penelitian ini sejalan dengan penelitian yang dilakukan oleh Sari dan Satria (2018) mengenai "Hubungan dukungan keluarga dengan kualitas hidup lansia osteoarthritis di Wilayah Kerja Puskesmas Muaro Paiti Kecamatan Kapur IX" menunjukkan adanya hubungan yang signifikan antara dukungan keluarga dengan kualitas hidup lansia di Muaro Paiti Kecamatan Kapur IX.

\section{SIMPULAN}

Hasil penelitian ini dapat diambil kesimpulan bahwa gambaran mayoritas dukungan keluarga dengan kategori baik sebanyak 88 orang $(70.4 \%)$, dan mayoritas kualitas hidup lansia kategori baik sebanyak 112 orang $(89.6 \%)$.

Hasil uji statistik uji Fisher's diperoleh nilai $p$ value $=0.000$ ( $p$ value $<$ 0.05), berarti Ho ditolak sehingga dapat disimpulkan bahwa ada hubungan yang signifikan antara dukungan keluarga dengan kualitas hidup lansia pada masa Covid-19 di Wilayah Kerja Puskesmas Payung Sekaki Pekanbaru. Nilai Odd Ratio 41.760 artinya lansia yang dukungan keluarga baik maka kualitas hidupnya mempunyai peluang 41.760 kali lebih baik.

\section{DAFTAR PUSTAKA}

Dewi, S. R. (2014). Buku ajar keperawatan gerontik. Yogyakarta: DEEPUBLISH

Dinkes. (2020). Jumlah penduduk dan sasaran perpuskesmas tahun 2020 Kota Pekanbaru. Pekanbaru: Dinas Kesehatan.

Dinkes. (2021, Januari). Update COVID-19 Provinsi Riau. Diperoleh tanggal 07 Januari 2021 dari http://corona.riau.go.id/.

Hayulita, S., Bahasa, A., \& Sari, A. N. (Juli, 2018). Faktor dominan yang berhubungan dengan kualitas hidup lansia. Afivah, 42-46. Diperoleh tanggal 31 Januari 2021 dari http://ejournal.stikesyarsi.ac.id/index. php/JAV1N1/article/viewFile/172/25 4\#: :text=Hasil\%20penelitian $\% 20 \mathrm{me}$ nunjukkan\%20bahwa\%20terdapat,ber hubungan $\% 20$ dengan $\% 20$ kualitas $\% 2$ 0hidup\%20lansia.

Harnilawati. (2013). Konsep dan proses keperawatan keluarga. Sulawesi Selatan: Pustaka As salam.

Kementerian Kesehatan RI. (2017, Januari 03). Analisis lansia di Indonesia 2017. Diperoleh tanggal 08 Agustus 2020 dari https://pusdatin.kemkes.go.id/article/v iew/18012600001/analisis-lansia-diindonesia-2017.html

Kementerian Kesehatan RI. (2014, Mei 29). Situasi dan analisis lanjut usia. Diperoleh tanggal 08 Agustus 2020 dari

https://www.kemkes.go.id/article/vie w/14010200005/situasi-dan-analisislanjut-usia.html

Kementerian Kesehatan RI. (2020, Maret 16). Situasi COVID-19 Informasi lain. Diperoleh tanggal 08 Agustus 2020 dari https://Covid19.kemkes.go.id/situasiinfeksi-emerging/info-coronavirus/situasi-terkini-perkembangancoronavirus-disease-Covid-19-16maret-2020/\#.X0eh-sgzbIV

Kementerian Kesehatan RI. (2020). Panduan pelaynan kesehatan lanjut usia pada era pandemi Covid-19. Diperoleh tanggal 19 Februari 2021 
dari

https://kesga.kemkes.go.id/assets/file/ pedoman/Panduan $\% 20$ Pelayanan $\% 20$ Kesehatan\%20Lansia\%20Era\%20Co vid19.pdf

Kementerian Kesehatan RI. (2020). Pedoman pencegahan dan pengendalian Coronavirus Disease (Covid-19). Jakarta: Kementerian Kes RI.

Kirana, J., Rajagukguk, K. P., \& Lubis E. L. S. (Juni, 2020). Analisis dampak Covid-19 pada masyarakat Sumatera Utara. Lembaga publikasi ilmiah mahasiswa Jurnal ilmiah mahasiswa Prodi pgsd, 64-69. Diperoleh tanggal 08 Agustus $2020 \quad$ dari https://jurnal.stkipalmaksum.ac.id/ind ex.php/jim/article/view/75/84.

Muhith, A. (2016). Pendidikan keperawatan gerontik edisi 1 . Yogyakarta: Andi.

Permensos. (2018, Juni 21). Standar nasional rehabilitasi sosial lanjut usia. Diperoleh tanggal 17 Agustus 2020 dari https://peraturan.bpk.go.id/Home/Det ails/129964/permensos-no-5-tahun2018

Ummah, A. C. (2016). Hubungan kebutuhan spiritual dengan kualitas hidup pada lansia di panti wredha kota Semarang. September 27, 2016. Universitas Diponegoro. http://eprints.undip.ac.id/49604/1/PR OPOSAL_Athurrita_Choirru_Umma h.pdf

Pratiwi, Y. (2015). Pengaruh dukungan sosial terhadap kualitas hidup lanjut usia di pusat satuan keluarga (PUSAKA) kecamatan pancoran Jakarta Selatan. Juli 25, 2016. Universitas Islam Negeri Syarif hidayatullah Jakarta. http://repository.uinjkt.ac.id/dspace/bi tstream/123456789/31977/1/YUSNIA \%20PRATIWI-FDK.pdf

Sari, Y. P., \& Satria, L. O. (2018). Hubungan dukungan keluarga dengan kualitas hidup lansia osteoarthritis di
Wilayah Kerja Puskesmas Muaro Paiti Kecamatan Kapur IX. Prosiding Seminar Kesehatan Perintis E-ISSN, 2622-2256. Diperoleh tanggal 1 Januari 2021 dari https://jurnal.stikesperintis.ac.id/index .php/PSKP/article/download/83/73/.

Siagian, T. H. (Juni, 2020). Mencari kelompok berisiko tinggi terinfeksi virus corona dengan discourse network analysis. Jurnal Kebijakan Kesehatan Indonesia, 98-106. Diperoleh tanggal 08 Agustus 2020 dari

https://jurnal.ugm.ac.id/jkki/article/vi ew/55475/27989.

Tim Dosen Fakultas Kedokteran Unisba. (2020). Kopidpedia. Bandung: P2U Unisba

Tristanto, A. (Agustus, 2020) Dukungan kesehatan jiwa dan psikososial (dkjps) dalam pelayanan sosial lanjut usia pada masa pandemi Covid-19. Sosio Informa, 205-222. Diperoleh tanggal 31 Januari 2021 dari https://ejournal.kemsos.go.id/index.ph $\mathrm{p} /$ Sosioinforma/article/view/2348/119 5.

Walayu, A., \& Muhamad, D. (2018). Hubungan dukungan keluarga dengan kualitas hidup lansia di RW 10 Kelurahan Cisarua wilayah kerja Puskesmas Sukabumi Kota Sukabumi. Lentera Jurnal Ilmu Kesehatan dan Keperawatan, 71-82. Diperoleh 08 Agustus 2020 dari https://jurnal.ummi.ac.id/index.php/le ntera/article/view/215/84

Worldmeter. (2020). Coronavirus update (live). Diperoleh tanggal 07 Januari 2021 dari https://www.worldometers.info/coron avirus/.

World Health Organization (WHO). (2012) Programme On Mental Health: Instrument Quality of Life BREF. Diperoleh tanggal 09 Agustus 2020 dari http://www.who.int.mental_health/pu blications/whoqol/en/ 